\title{
A case of nodular lymphocyte predominant Hodgkin lymphoma with unexpected EBV-latency type
}

\author{
Mathias T. Rosenfeldt ${ }^{1,2} \cdot$ Elena M. Hartmann ${ }^{1,2} \cdot$ Corinna Leng $^{3} \cdot$ Andreas Rosenwald $^{1,2} \cdot$ Ioannis Anagnostopoulos $^{1}$
}

Received: 19 May 2020 / Accepted: 9 July 2020 / Published online: 19 July 2020

(C) The Author(s) 2020

Dear Editor,

Hodgkin lymphoma (HL) comprises two major entities: classic Hodgkin lymphoma (CHL) in $>90 \%$ of cases and nodular lymphocyte predominant Hodgkin lymphoma (NLPHL) in the remaining $5-10 \%$. Both are of B cell origin, but only NLPHL generally retains the B cell programme [1-3]. Only a minority (4-5\%) of NLPHL are associated with EpsteinBarr virus (EBV, human herpesvirus 4 (HHV-4)), whereas in CHL, EBV can be found in up to $50 \%$ of cases [1-3]. EBV infection affects $>90 \%$ of adults worldwide. Primary infection is mostly asymptomatic but leads to a persistent latent infection [4]. EBV dormancy is characterised by specific latency programmes with differential expression of viral noncoding RNAs (e.g. EBV-encoded RNAs, EBERs), latent membrane proteins (LMPs) and EBV-nuclear antigens (EBNAs). EBERs are found in all latency states, whereas LMPs and EBNAs are variably expressed [5, 6]. Latency type II with expression of LMP1 and positive in situ hybridization (ISH) for EBERs is nearly ubiquitous in EBV-associated CHL. The latency pattern for EBV-positive NLPHL is not precisely established $[1,2,6,7]$.

We present a case of NLPHL with an unusual EBV latency type. We received a formalin fixed paraffin-embedded cervical lymph node of a 60 -year-old female patient of Iranian

Mathias T. Rosenfeldt

mathias.rosenfeldt@uni-wuerzburg.de

1 Institute of Pathology, University of Wuerzburg, Josef-Schneider Str. 2, 97080 Wuerzburg, Germany

2 Comprehensive Cancer Center Mainfranken, Josef-Schneider Str. 6, 97080 Wuerzburg, Germany

3 Division of Hematology, Oncology, and Tumor Immunology, Campus Benjamin Franklin, Charité-Universitätsmedizin Berlin, Hindenburgdamm 30, 12203 Berlin, Germany descent. She presented with B-symptoms, cervical, abdominal and inguinal lymphadenopathy and splenomegaly. The past medical history and laboratory parameters were largely unremarkable. Lymph node architecture was effaced by a nodular infiltrate composed predominantly of small lymphocytes, histiocytes, sparse eosinophils and intermingled larger atypical cells, some with features of Hodgkin- and Reed-Sternberg cells, and others of LP cells (Fig. 1a, b, c). Morphology prompted a differential diagnosis of nodular sclerosis $\mathrm{CHL}$ vs the rare case of NLPHL with occasional eosinophils. Atypical cells co-expressed CD20 (Fig. 1d), CD79a, CD75, OCT-2, BOB.1 and BCL6, while CD30 was detected only in single, non-neoplastic bystander cells. CD21 highlighted the presence of follicular dendritic cell meshworks with embedded tumour cells. Immunohistochemistry for PD1 identified rosettes of PD1-positve T cells that surrounded LP-cells. Clonality analysis employing the BIOMED-2 protocol ruled out the presence of a clonal $\mathrm{T}$ cell population. These findings prompted a diagnosis of NLPHL and ruled out all differential diagnoses. Repeated immunostaining for LMP-1 was negative (Fig. 1e). Unexpectedly, a majority of tumour cells harboured EBER transcripts, albeit a minority remained negative (Fig. 1f), indicating a latency gene expression pattern other than type II, potentially type I. Moreover, sparse EBER-ISHpositive small lymphoid cells of the microenvironment were detectable. The literature covering EBV in NLPHL is limited $[2,8,9]$. Positive EBER-ISH and LMP1 expression have been reported, as well as positive EBER-ISH but negativity for LMP1 and even a case with probably artificially negative EBER-ISH and positivity for LMP1 [2, 8, 9]. Nonetheless, the available literature implies that unlike CHL, NLPHL is not unequivocally associated with a certain EBV latency gene expression pattern. We postulate that NLPHL demonstrates a broad spectrum of EBV latency patterns and that it is worthwhile to examine these in order to gain further insights into the complexity of this disease. 
Fig. 1 a-f Representative images stained as indicated. Scale bars in the top two panels represent $500 \mu \mathrm{m}$, whereas in the other panels, they represent $20 \mu \mathrm{m}$
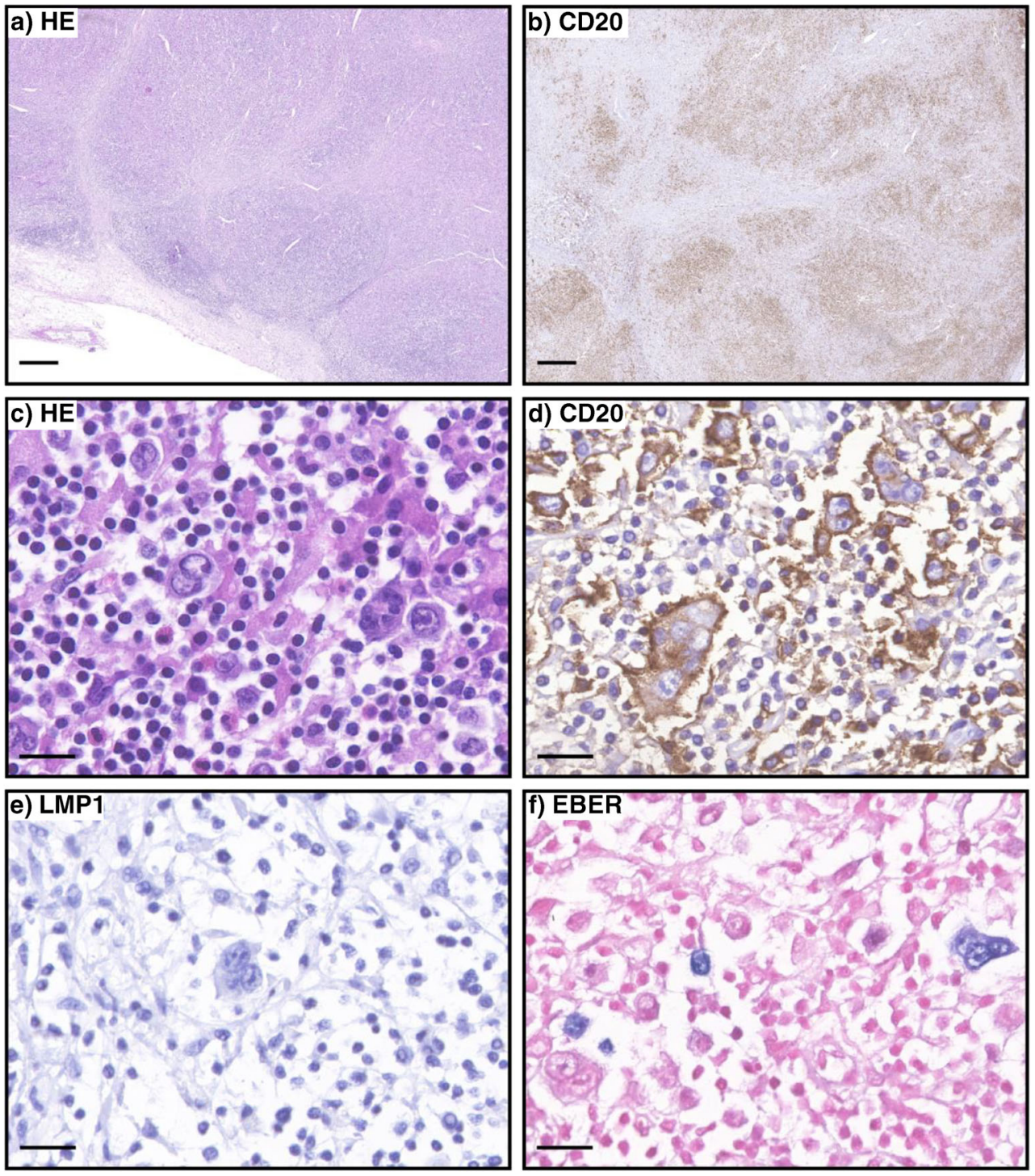

Authors' contributions MTR, EMH, IA and AR were responsible for pathology and manuscript preparation, and CL provided anonymised clinical data.

Funding Information Open Access funding provided by Projekt DEAL.

\section{Compliance with ethical standards}

Conflict of interest The authors declare that they have no competing interests.

Ethics approval Ethical approval was granted from the relevant institutions.

\section{Consent to participate Not applicable}

Consent for publication Not applicable
Open Access This article is licensed under a Creative Commons Attribution 4.0 International License, which permits use, sharing, adaptation, distribution and reproduction in any medium or format, as long as you give appropriate credit to the original author(s) and the source, provide a link to the Creative Commons licence, and indicate if changes were made. The images or other third party material in this article are included in the article's Creative Commons licence, unless indicated otherwise in a credit line to the material. If material is not included in the article's Creative Commons licence and your intended use is not permitted by statutory regulation or exceeds the permitted use, you will need to obtain permission directly from the copyright holder. To view a copy of this licence, visit http://creativecommons.org/licenses/by/4.0/.

\section{References}

1. Hartmann S, Eichenauer DA (2020) Nodular lymphocyte predominant Hodgkin lymphoma: pathology, clinical course and relation to T-cell/histiocyte rich large B-cell lymphoma. Pathology 52(1):142153. https://doi.org/10.1016/j.pathol.2019.10.003 
2. Piris MA, Medeiros LJ, Chang KC (2020) Hodgkin lymphoma: a review of pathological features and recent advances in pathogenesis. Pathology 52(1):154-165. https://doi.org/10.1016/j.pathol.2019.09. 005

3. Gobbi PG, Ferreri AJ, Ponzoni M, Levis A (2013) Hodgkin lymphoma. Crit Rev Oncol Hematol 85(2):216-237. https://doi.org/10. 1016/j.critrevonc.2012.07.002

4. Thorley-Lawson DA, Gross A (2004) Persistence of the Epstein-Barr virus and the origins of associated lymphomas. N Engl J Med 350(13):1328-1337. https://doi.org/10.1056/NEJMra032015

5. Dugan JP, Coleman CB, Haverkos B (2019) Opportunities to target the life cycle of Epstein-Barr virus (EBV) in EBV-associated lymphoproliferative disorders. Front Oncol 9:127. https://doi.org/10. 3389/fonc. 2019.00127

6. Price AM, Luftig MA (2015) To be or not IIb: a multi-step process for Epstein-Barr virus latency establishment and consequences for B cell tumorigenesis. PLoS Pathog 11(3):e1004656. https://doi.org/10. 1371/journal.ppat.1004656
7. Shannon-Lowe C, Rickinson AB, Bell AI (2017) Epstein-Barr virusassociated lymphomas. Philos Trans R Soc Lond Ser B Biol Sci 372(1732):20160271. https://doi.org/10.1098/rstb.2016.0271

8. Huppmann AR, Nicolae A, Slack GW, Pittaluga S, Davies-Hill T, Ferry JA, Harris NL, Jaffe ES, Hasserjian RP (2014) EBV may be expressed in the LP cells of nodular lymphocyte-predominant Hodgkin lymphoma (NLPHL) in both children and adults. Am J Surg Pathol 38(3):316-324. https://doi.org/10.1097/PAS. 0000000000000107

9. Wang S, Medeiros LJ, Xu-Monette ZY, Zhang S, O'Malley DP, Orazi A, Zuo Z, Bueso-Ramos CE, Yin CC, Liu Z, Miranda RN, Young KH (2014) Epstein-Barr virus-positive nodular lymphocyte predominant Hodgkin lymphoma. Ann Diagn Pathol 18(4):203209. https://doi.org/10.1016/j.anndiagpath.2014.03.007

Publisher's note Springer Nature remains neutral with regard to jurisdictional claims in published maps and institutional affiliations. 